\title{
Ground-level ozone in China: Distribution and effects on crop yields
}

\author{
Xiaoke Wang ${ }^{\mathrm{a}, *}$, William Manning ${ }^{\mathrm{b}}$, Zongwei Feng ${ }^{\mathrm{a}}$, Yongguan Zhu ${ }^{\mathrm{a}}$ \\ ${ }^{a}$ Research Center for Eco-Environmental Sciences, Chinese Academy of Sciences, Beijing 100085, China \\ ${ }^{\mathrm{b}}$ Department of Plant, Soil and Insect Sciences, University of Massachusetts, Amherst, MA 01003-9320, USA
}

Received 3 May 2006; accepted 3 May 2006

More research is needed to reliably estimate ozone caused crop losses in China.

\begin{abstract}
Rapid economic development and an increasing demand for food in China have drawn attention to the role of ozone at pollution levels on crop yields. Some assessments of ozone effects on crop yields have been carried out in China. Determination of ozone distribution by geographical location and resulting crop loss estimations have been made by Chinese investigators and others from abroad. It is evident that surface level ozone levels in China exceed critical levels for occurrence of crop losses. Current levels of information from ozone dose/response studies are limited. Given the size of China, existing ozone monitoring sites are too few to provide enough data to scale ozone distribution to a national level. There are large uncertainties in the database for ozone effects on crop loss and for ozone distribution. Considerable research needs to be done to allow accurate estimation of crop losses caused by ozone in China.
\end{abstract}

(C) 2006 Elsevier Ltd. All rights reserved.

Keywords: Ozone effect; Crop loss; China

\section{Introduction}

As the most populous country in the world, China must provide food for one fifth of the world's population with only $7 \%$ of the world's land area. After nearly three decades of effort, China produced 0.43 billion tons of grain in 2003, which met the country's minimum food requirement (Xinhua News Agency, 2004). Grain production, however, is threatened by agricultural land loss due to economic development and urbanization and air pollution effects on yields. The Chinese government has addressed the land loss issue by passing laws to protect agricultural land. Yield losses due to air pollution, especially ozone, have received little governmental attention, even though there are published reports that ground-level ozone may be adversely affecting grain production (Chameides et al., 1999; Feng et al., 2003; Wang and Mauzerall, 2004; Wang et al., 2005).

\footnotetext{
* Corresponding author. Tel./fax: +86 1062943822.

E-mail address: wangxk@mail.rcees.ac.cn (X. Wang).
}

Economic expansion in China is driven by increasingly higher consumption of fossil fuels. Primary energy consumption increased by 53\% from 1990 to 2002. In 2002, primary energy consumption was 1.514 billion coal equivalent tons, of which $66.3 \%$ was coal, $23.5 \%$ was oil, and $2.6 \%$ natural gas. Energy consumption is estimated to reach 4 billion coal equivalent tons in 2020 (China Energy Middle-Long-Term Development Plan). In the future, more than $75 \%$ of energy will be derived from fossil fuels. Measures to limit electricity consumption now were established in China in 2003.

Increasing consumption of fossil fuels in China results in increased emissions of sulfur oxides (SOx) and nitrogen oxides (NOx) as well as soot and fine particulates and carbon dioxide. In Europe and North America, emissions from fossil fuel consumption are decreasing, while in China, they are rapidly increasing, especially in cities and industrial areas (He et al., 2002; Coyle et al., 2003; Ashmore, 2005). NOx includes both nitrogen dioxide $\left(\mathrm{NO}_{2}\right)$ and nitric oxide (NO). $\mathrm{NO}_{2}$ is the starting point for the photochemical oxidant cycle that results in formation of ozone. Increasing levels of NOx also means increasing levels of ozone in China. 
The Yangtze Delta is one of the world's continental scale Metro-Agro-Plexes (MAPs). As Chameides et al. (1994) point out, the growth of MAPS results in increased ground-level ozone to pollution levels. Yet few papers have estimated present and future crop losses from ozone in the Yangtze Delta and elsewhere in China. There is an urgent need to address this problem. Here we present what is known about current distribution of surface levels of ozone and their effects on crop yields and consideration of how to improve crop loss estimates for current and future levels of ozone in China.

\section{Surface level ozone distribution and implications for crop losses}

In the 1980s, air pollution began to receive attention in China. Air quality monitoring stations were established by the government in cities, such as Beijing and Shanghai, and capitals of the provinces. In many cities, SOx, NOx, and particulates are monitored routinely (He et al., 2002). There are only a few ozone analyzers in some of the large developed cities in eastern coastal areas. Little of the ozone monitoring data is available.

Individual Chinese scientists have established ozone-monitoring programs. As early as 1983, Su et al. (1987) began monitoring ozone in the Beijing-Tianjing Region, in collaboration with W.E. Wilson, Atmospheric Science Research Laboratory, US EPA. Since then, ozone monitoring has been carried out at urban, suburban and rural sites (Fig. 1). Due to equipment shortages and problems with funding and logistics, records from these sites are often short-term and or incomplete.

Two projects supported by the National Nature Science Foundation of China focused on ozone monitoring on a countrywide scale. Project PRO1 focused on five sites, with monitoring data available from August 1994 to July 1995. The five sites included: a WMO baseline station (Waliguan site); two WMO regional baseline stations (Longfeng Shan and Linan sites); a CEPA monitoring site (Qindao site); and a background station in Hong Kong (Luo et al., 2000). Project PRO2 focused on six sites in the Yangtze Delta: one of the most highly polluted areas in China. Ozone was monitored at Changsu, Linan, Shesan, Jiaxing, Jianhu and Jurong from June 1999 to June 2000 (Zhou, 2004).

Looking at the data for all locations, the maximum hourly mean ozone concentrations were larger than $56 \mathrm{ppb}$, suggesting that they could cause crop losses. Ozone concentrations were not highest in urban areas. In Guanzhou, for example, ozone concentrations were of the order urban $<$ suburban $<$ rural areas. In remote areas, such as the Emei and Taishan sites, ozone concentrations are high (Table 1).

This implies that crops in these regions might be damaged by high ozone concentrations. Su et al. (1987) found that ozone exceeded $80 \mathrm{ppb}$ on $50 \%$ of the days they monitored in the Beijing-Tianjin region, with a maximum reading of $170 \mathrm{ppb}$ reported during 1983-1986. Results from recent ozone monitoring in the Yangtze Delta shows that $6.1-10.4 \%$ of the hourly mean concentrations exceeded $60 \mathrm{ppb}$. A maximum high concentration of ozone at $196 \mathrm{ppb}$ was reported from Sheshan, near Shanghai (Zhou, 2004).

In most locations, ozone concentrations were lower in the winter. Peak concentrations vary with location (Table 1). At the central station of Guangzhou city, Guangdong Province in 1999, the seasonal mean and maximal ozone concentrations were $23 \mathrm{ppb}$ and $55 \mathrm{ppb}$ in spring, $24 \mathrm{ppb}$ and $53 \mathrm{ppb}$ in summer, $34 \mathrm{ppb}$ and $76 \mathrm{ppb}$ in fall, and $39 \mathrm{ppb}$ and $82 \mathrm{ppb}$ in winter (Wang et al., 2003). In PRO1 peaks occurred in fall/early winter (Luo et al., 2000). In PRO2, peaks occurred in summer, followed by fall. Summer and fall are times when crops are growing fast. Peaks of ozone during these times could result in crop losses.

Multiple-day episodes of high ozone concentrations have been noted at some sites in Eastern China, due to the presence of a strong and stationary high-pressure ridge (Luo et al., 2000). The impacts of these episodes on crop production, however, are unknown.

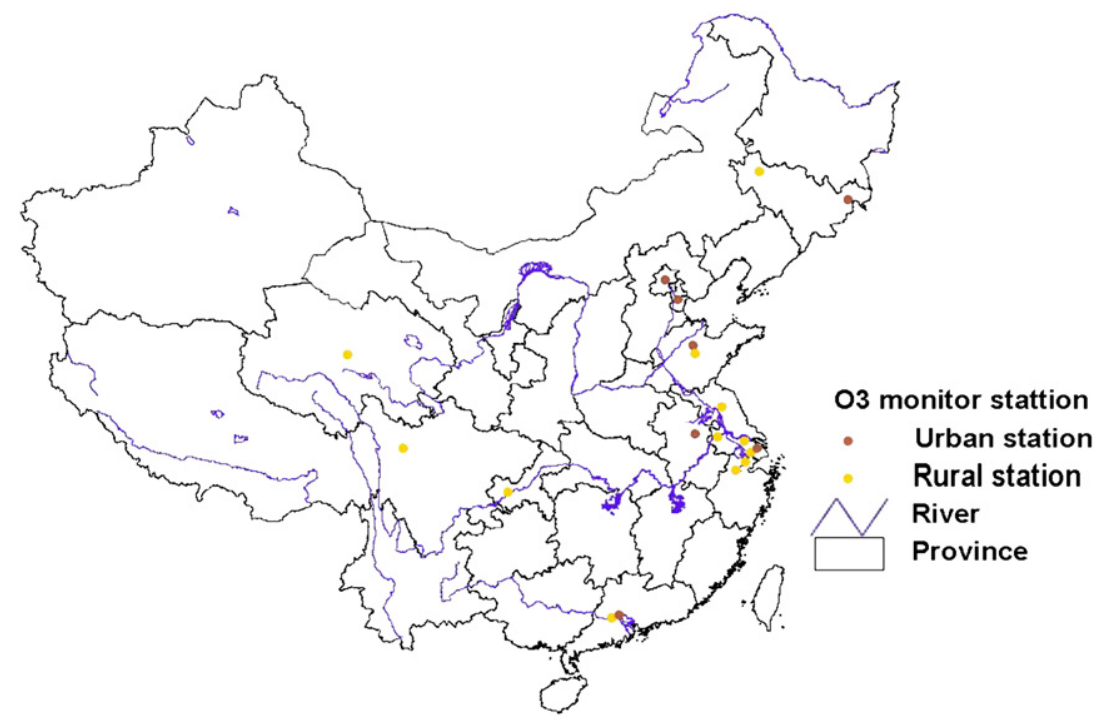

Fig. 1. The distribution of $\mathrm{O}_{3}$ monitoring stations in China. 
Table 1

Mean $\mathrm{O}_{3}$ concentrations at monitoring sites by season

\begin{tabular}{|c|c|c|c|c|c|c|c|c|c|}
\hline \multirow[t]{2}{*}{ Site } & \multirow[t]{2}{*}{ Location } & \multirow[t]{2}{*}{ Measurement period } & \multicolumn{6}{|c|}{ Concentration (ppb) } & \multirow[t]{2}{*}{ Reference } \\
\hline & & & Annual & Spring & Summer & Fall & Winter & $\begin{array}{l}\text { Hourly } \\
\text { maximum }\end{array}$ & \\
\hline Beijing-Tianjin region & Urban & $1983-1986$ & 45 & 32 & 45 & 67 & 37 & 170 & Su et al., 1987 \\
\hline Mount Omei & Rural & 8-20 Oct. 1985 & & & & & 25 & $56^{*}$ & Hong, 1988 \\
\hline Xiaozhangzhuang, Hefei & Suburban & Oct. 1993 & & & & & 24 & 57.9 & Yao et al., 1995 \\
\hline DongquXiaoyuan, Hefei & Urban & Oct. 1993 & & & & & 19.8 & 65.6 & Yao et al., 1995 \\
\hline Waliguan & Rural & Aug. 1994-Jul. 1995 & & & & & & 130 & Li et al., 1999 \\
\hline Longfengshan & Rural & Aug. 1994-Jul. 1995 & & & & & & 80 & Li et al., 1999 \\
\hline Linan & Rural & Aug. 1994-Jul. 1995 & & & & & & 120 & Li et al., 1999 \\
\hline Qingdao & Rural & Aug. 1994-Jul. 1995 & & & & & & 90 & Li et al., 1999 \\
\hline Jinhushan & Rural & Jul. 1998-Jun. 1999 & 20 & 21 & 16 & 15 & 27 & $55^{*}$ & Bai et al., 2003 \\
\hline $\begin{array}{l}\text { Central Station, } \\
\text { Guangzhou }\end{array}$ & Urban & Jan.-Dec. 1999 & 59 & 45 & 47 & 66 & 77 & 161 & Wang et al., 2003 \\
\hline Luhu Park, Guangzhou & Suburban & Jan.-Dec. 1999 & 74 & 74 & 71 & 75 & 74 & 180 & Wang et al., 2003 \\
\hline Longgui, Guangzhou & Rural & Jan.-Dec. 1999 & 74 & 59 & 77 & 75 & 84 & 174 & Wang et al., 2003 \\
\hline Changshu & Rural & Jun. 1999-Oct 2000 & 31 & 25 & 45 & 28 & 26 & $120 *$ & Zhou, 2004 \\
\hline Linan & Rural & Jun. 1999-Oct. 2000 & 35 & 29 & 43 & 29 & 37 & $136^{*}$ & Zhou, 2004 \\
\hline Sheshan & Rural & May 1999-Jun. 2000 & 33 & 31 & 43 & 28 & 31 & $196^{*}$ & Zhou, 2004 \\
\hline Jiaxing & Rural & May 1999-Jun. 2000 & 29 & 35 & 40 & 27 & 12 & $188 *$ & Zhou, 2004 \\
\hline Jianhu & Rural & May 1999-Dec. 1999 & & & 41 & 27 & 32 & $114 *$ & Zhou, 2004 \\
\hline Jurong & Rural & Dec. 1999-Jun. 2000 & & 17 & 37 & & & $141 *$ & Zhou, 2004 \\
\hline Waliguan, Qinghai & Rural & Aug. 1994-Dec. 2001 & 48 & 44.9 & 54.2 & 50.6 & 41.5 & 65 & Nie et al., 2004 \\
\hline Hongkou, Shanghai & Urban & Jan.-Dec. 2002 & 19 & 20.5 & 21 & 23.5 & 12 & 128 & Zhang et al., 2003 \\
\hline Yanji, Jilin & Urban & Mar.-May 2003 & & 29 & 19 & & & 48.8 & Li et al., 2003 \\
\hline Jinan, Shangdong & Urban & May-Oct. 2003 & & & 54.5 & 46.5 & 30 & 316 & Yin et al., 2004 \\
\hline Taishan, Shandong & Rural & Jul.-Nov. 2003 & & & 62 & 49 & & 120 & Gao et al., 2005 \\
\hline Jiangbei, Chongqing & Rural & $1993-1996$ & & 7 & 8 & 21 & & 93 & Zheng et al., 1998 \\
\hline
\end{tabular}

*Maximum $\mathrm{O}_{3}$ concentration monitored.

Long-term ozone monitoring data from established sites in China is either non-existent or not readily available. There is a WMO baseline monitoring site at Wanliguan that has been active for more than 10 years. Data from 1994 to 2001 indicate a linear increment trend for ozone in a 9\% slope (Nie et al., 2004).

Many descriptors can be used to express cumulative ozone data in relation to crop loss. Indices such as mean and cumulative can be based on timescales such as hourly, daily, monthly, seasonally and yearly. Initially a 7-hour (09:00-16:00) seasonal mean index (M7) was proposed. This was later extended to a 12-hour (08:00-20:00) seasonal mean index (M12) to include late day high ozone concentrations (Hogsett et al., 1988). Since then, cumulative indices have become more widely used (SUM 0, SUM60, W126).

SUM0 is the sum of all ozone exposure in ppb or ppm hours. SUM60 is the accumulated hourly mean ozone concentrations in three consecutive months at $60 \mathrm{ppb}$ and above, expressed as ppb or ppm hours. W126 weights the accumulated hourly means to give preference to higher values. SUM60 and W126 have been used to analyze crop loss due to ozone (US EPA, 1996; Wang and Mauzerall, 2004). The European Union has developed the AOT40 cumulative index. This includes hourly ozone averages at $40 \mathrm{ppb}$ and above during daylight hours during the growing season, expressed as ppm hours.

In project PRO2, SUM06, AOT40 and M7 indices were calculated for the period of April to June in Changsu, Shesan, Linan, Jurong, and Jiaxing. The relationship between SUM06 and AOT40 was strong and significant $\left(r^{2}=0.97\right)$, while both were weakly related to M7 $\left(r^{2} \leq 0.1\right)$ (Zhou, 2004). Averages for SUM60, AOT40, and 7M for the five stations in the wheat-growing period from April to June were $33 \mathrm{ppm} \mathrm{h}, 19 \mathrm{ppm} \mathrm{h}$, and $59 \mathrm{ppb}$ (Wang et al., 2005).

China is a very large country with many climatic regions. This makes application of exposure indices difficult as the crops and cropping practices are different in each region and are subject to varying climatic influences. The periods of consecutive months for calculating indices will vary with each location.

In China, the main crops are winter wheat, oilseed rape, rice, corn and soybeans. Except for Northeastern China, where crops are limited by precipitation and temperature, and parts of Southwestern China, where crops are limited by temperature, more than one crop is planted during one year. Spring and fall seasons are the most important seasons for growing crops. Elevated ozone concentrations during these times could adversely affect crop growth and yields.

Calculations of seasonal changes in SUM60 were made for Longfeng San, Qingdao, Linan, and Hong Kong (Fig. 3 in Chameides et al., 1999). Taking local cropping practices into account, assessment of ozone impact on crop yields can be determined. Corn and soybean are sown in Longfen San in May and harvested in September. SUM06 was highest there from September to January of the next year. This indicates that ozone effects on corn and soybeans there would likely be small. In Linan, winter wheat and rape are sown in late winter and harvested in May. Corn and rice are sown in June and harvested in October. While SUM60 values are higher here, they occur during early season slow crop growth periods. In Hong 
Kong, SUM60 values peak from October to December, when much cropland is fallow. In Qindao, SUM60 values peak from July to September and could seriously affect yields of later seasonal crops of corn and rice.

\section{Plant responses to ozone in China}

\subsection{Screening plants for ozone sensitivity by exposure to ozone in chambers}

A wide variety of plants have been screened for sensitivity to ozone, based on foliar injury expression following exposure under controlled conditions (Table 2). Wheat seemed to be one of the most sensitive crop plant under these conditions (Jin et al., 2001). Variation in sensitivity within genotypes was also noted, especially for tobacco (Yang et al., 2004).

\subsection{Short-term investigations in open-top chambers (OTCs)}

Short-term experiments (most less than one month) were done with ozone and a variety of plants in OTCs. Aspects of visible symptom expression, microanatomical effects, reproduction, nutrient status, stomatal physiology, antioxidant responses, pollen development and ethylene emission were investigated. (Wang and Guo, 1990; Huang and Wang, 1991; Huang et al., 2004; Wang and Men, 1991; An and Wang, 1994; Qiu et al., 1994; and Yu et al., 1994; Jiang and Totsuka, 1995; Sun et al., 1998; Jin and Feng, 2000; Jin et al., 2000; Bai et al., 2002; Yang et al., 2004; Huang et al., 2004). Results of these investigations, while useful, cannot be extrapolated to crop loss studies and are mentioned here to provide a complete record of research done on ozone effects on plants in China.

\subsection{Long-term crop loss studies with OTCs in the field}

The National Nature Science Foundation of China supported an OTC dose/response study with wheat and rice in
Hebei Province. The Chinese Academy of Meteorological Sciences established 5 OTCs in Dingxing. Wheat and rice were exposed to either non-filtered air (NF), charcoal-filtered air (FA), FA $+50 \mathrm{ppb}$ ozone, FA $+100 \mathrm{ppb}$ ozone, or $\mathrm{FA}+200 \mathrm{ppb}$ ozone for 3-4 months. Only one OTC was used for each ozone exposure regime. When crop yields for wheat were compared to those from FA + ozone at 50, 100, and $200 \mathrm{ppb}$, reductions of $10.5,58.6$, and $80.4 \%$ occurred. Similar comparisons for rice resulted in reductions of 8.2 , 26.1 and $49.1 \%$ for rice (Feng et al., 2003).

Using these results, Jin et al. (2001) proposed the following dose/response relationships for wheat and rice:

$Y_{\text {wheat }}=-1.296 x$

$Y_{\text {rice }}=-0.256 x$

where $Y_{\text {wheat }}$ and $Y_{\text {rice }}$ are \% yield losses and $x$ is an AOT40 in ppm $h$ during the exposure period. From this, it was concluded that yield loss for wheat was 5 times that for rice at the same ozone exposure regimes.

\subsection{Other yield effects investigations}

Huang et al. (2004) exposed soybean plants to $100 \mathrm{ppb}$ ozone and obtained a yield reduction of $60 \%$. They concluded that soybean was more sensitive to ozone than wheat. Pakchoi biomass was reduced by $38-84 \%$ and $69-86 \%$ after exposure to ozone at 100 or $200 \mathrm{ppb}$ for 20 days (Bai et al., 2002).

\section{Chemical treatments to prevent ozone injury}

Wang and his colleagues have evaluated a variety of chemical compounds to prevent ozone injury on plants in China (Table 3). The experiments, however, were all of short duration and very high ozone concentrations were used. Additional work involving using these chemical compounds under ambient conditions might lead to useful results.

Table 2

Results and screening studies for ozone sensitivity in crop plants

\begin{tabular}{|c|c|c|}
\hline Authors & Indicator for assessment & Results \\
\hline Zheng et al., 1998 & $\begin{array}{l}\text { Growth response to exposure of } \\
\text { elevated } \mathrm{O}_{3} \text { of } 15 \mathrm{ppb} \text { overnight } \\
\text { rising to a midday maximum of } \\
75 \mathrm{ppb} \text { for } 28 \text { days }\end{array}$ & $\begin{array}{l}\text { Nicotiana tabacum 'Bel-W3' }>\text { Planago major 'Valsain' }>\text { Triticum Aestivum 'Hanno' }> \\
\text { Raphanus sativa 'Cherry Bell' }>\text { Capsicum annum 'Yu2' }>\text { Capsicum annum 'Yu3' }>\text { Oryza } \\
\text { sativa 'Xiaoyou 2' > Capsicum annum 'Yu4' > Capsicum annum 'Yu5' }>\text { Solanum melongena } \\
\text { 'Sanyue' }>\text { Brassica oleracea 'Mogu' }>\text { Brassica pekinensis 'Lubei 1' }>\text { Lycopersicon } \\
\text { esculentum '85004' > Lactuca sativa 'Erqingpi' > Triticum aestivum 'Yumai 4' }>\text { Zea mays } \\
\text { '3203' > Raphanus sativa '88059'>Cucurbita pepo 'Zhaoqin' }\end{array}$ \\
\hline Jin et al., 2001 & $\begin{array}{l}\text { Production reduction in exposure } \\
\text { to } \mathrm{O}_{3} \text { concentration of } 100 \text { and } \\
200 \mathrm{ppb} \text { for } 3 \text { months }\end{array}$ & $\begin{array}{l}\text { Spinacia oleracea 'Zhongbo 1'> Brassica chinensis 'Wuyueman' > Triticum aestivum } \\
\text { 'Jingdong 6' }>\text { Oryza sativa 'Zhongzuo 9321' }\end{array}$ \\
\hline Zhou and Feng, 2001 & $\begin{array}{l}\text { Symptoms with fumigation under } \\
150 \mathrm{ppb} \text { for } 0.5 \mathrm{~h}\end{array}$ & $\begin{array}{l}\text { Most sensitive vegetables: Spinacia oleracea, Cucumis sativus, Ipomoea aquatica, Lycopersicon } \\
\text { esculentum, Raphanus sativus, Capsicum annuum } \\
\text { Sensitive vegetables: Solanum melongena, Vigna unguiculata, Phaseolus Vulgaris, Brassica } \\
\text { pekinensis, Luffa cylindrica } \\
\text { Insensitive vegetables: Brassica alboglabra, Brassia juncea, Momordica charantia }\end{array}$ \\
\hline Yang et al., 2004 & $\begin{array}{l}\text { Flecks on leaf in exposure } \\
\text { to } \mathrm{O}_{3} \text { concentration of } \\
332 \mathrm{ppb} \text { for } 12 \mathrm{~h}\end{array}$ & Nacotiana tabacum 'K326' > 'NC628' > 'K346' > 'Yunyan 85'> 'Yunyan 87' \\
\hline
\end{tabular}


Table 3

Comparison and effectiveness of a variety of chemical compounds in prevention of ozone effects on plant

\begin{tabular}{|c|c|c|c|c|}
\hline Chemicals & Method & Plant & Results & Reference \\
\hline $\begin{array}{l}\text { Plant growth regulator, } \\
\text { Mefluidide }\end{array}$ & 10 ppm spray & Broadbean (Vicia faba) & $\begin{array}{l}\text { Photosynthesis recovery from } 0.2 \mathrm{ppm} \\
\mathrm{O}_{3} \text { fumigation for } 4 \mathrm{~h}\end{array}$ & Wang et al., 1991 \\
\hline $\begin{array}{l}\text { Fertilizer containing } \\
\quad \text { rare earth }\end{array}$ & $3 \mathrm{~g} / \mathrm{L}$ in a solvent spray & Wheat (Triticum aestivum) & $\begin{array}{l}\text { Preventing of reduction in chlorophyll, } \\
\text { and increase in membrane permeability } \\
\text { due to } \mathrm{O}_{3} \text { exposure }\end{array}$ & An and Wang, 1994 \\
\hline Magnetized water & Watering & Pepper (Capsicum annuum) & $\begin{array}{l}\text { Prevention of reduction in growth due to } \\
\mathrm{O}_{3} \text { exposure }\end{array}$ & Wang and Huang, 1999 \\
\hline $\mathrm{CaCl}_{2}$ & $\begin{array}{l}\text { Seeds soaked with } 3 \% \\
\mathrm{CaCl}_{2} \text { before planting }\end{array}$ & Wheat (Triticum aestivum) & $\begin{array}{l}\text { Preventing of reduction in chlorophyll, and } \\
\text { increase in membrane permeability due to } \\
\mathrm{O}_{3} \text { exposure }\end{array}$ & Wang et al., 1993 \\
\hline
\end{tabular}

Ethylenediurea ( $N$-[2-(2-oxo-1-imidazolidinyl)ethyl]- $N^{\prime}$ phenylurea), abbreviated as EDU, used as a foliar spray, soil/potting medium drench, or stem injection, is systemic and persistent in plants. It has been widely used to prevent foliar ozone injury and determine ozone effects on growth and yield of many plants (Gatta et al., 1997; Manning, 2000, 2005). Tiwari et al. (2005) used EDU with two cultivars of wheat in India and were able to demonstrate ozone effects on yields. Elagoz and Manning (2005) used EDU to assess ozone impact on snapbeans in Massachusetts. EDU is especially useful in areas where electricity and other infrastructure are limited.

\section{Ozone interactions with other gases}

\subsection{Sulfur dioxide}

In the USA, Canada and most of Europe, emissions of sulfur dioxide have been reduced by as much as $70 \%$ (Grennfelt and Munthe, 2005). In China, however, coal is used extensively and its use will increase in the future, unless emission controls are improved. The effects of combined exposure to sulfur dioxide and ozone on plants have not been investigated extensively in China. In one experiment, tobacco plants were exposed to ozone and sulfur dioxide alone and in combination for $8 \mathrm{~h}$ in OTCs. Synergism was found for effects on foliar injury when plants were exposed to both sulfur dioxide and ozone (Chen et al., 1996). EDU protects plants from ozone injury, but not from injury caused by sulfur dioxide. Its use in the field would allow identification of injury caused by ozone or sulfur dioxide.

\section{Projecting ozone concentration and resulting crop loss}

\subsection{Determining ozone distribution in China}

In recent years, models have been developed to estimate ozone distribution at various geographic scales (He and Huang, 1993; Chameides et al., 1999; Aunan et al., 2000; Luo et al., 2000; Wang and Mauzerall, 2004; Wu et al., 2004; Yang and Lu, 2004; Zhang et al., 2004; Zhao et al., 2004; Zheng et al., 2003). Ozone distribution for China was modeled, using MOZART-2, CTM, and updated RADM, by Wang and Mauzerall (2004) and Luo et al. (2000). Validating the models is difficult due to a lack of actual data. Wang and Mauzerall (2004) concluded that MOZART-2 over-estimated ozone concentrations for all but one month by several to $20 \mathrm{ppb}$ at the Lian site. Luo et al. (2000) concluded that their model could estimate key features of ozone distribution, but that there was a poor relationship in day-to-day variations in ozone at a given site between the model predictions and actual observations.

The highest ozone concentrations have occurred in the Yangtze Delta region where industry and population are concentrated. The SUM06 for the Yangtze Delta for the $1990 \mathrm{~s}$ were more than the $50 \mathrm{ppm} \mathrm{h}$ and $25 \mathrm{ppm} \mathrm{h}$ predicted by the models of Aunan et al. (2000) and Chameides et al. (1999).

\subsection{Projecting ozone concentrations}

Wang and Mauzerall (2004) predicted that in July 2020, surface ozone concentrations in central China will exceed $65 \mathrm{ppb}$, an increase of $15 \mathrm{ppb}$ over 1990 levels. Almost all exposure indices, except the 7-h mean, will increase dramatically for winter wheat. SUM06 for soybeans will increase by 6-70 ppb. Aunan et al. (2000) predict an increase for SUM06 (June-August) from less than $10 \mathrm{ppm} \mathrm{h}$ to $30-66 \mathrm{ppm}$ h by 2020 .

\subsection{Crop losses}

Rapid economic development has resulted in high ozone concentrations in the Yangtze River Delta and other sites, such as Lian. Using a variety of methods, several crop loss scenarios have been established or projected (Table 4). Feng et al. (2003) concluded a 10\% loss for wheat and 5\% for rice in the Yangtze River Delta in the 1990s. Aunan et al. (2000) and Wang et al. (2004) have estimated crop loss from ozone in China at $0-23 \%$. Increased ozone levels in the future may range from $2.3-64 \%$ (Table 4). Even though there are large uncertainties in these estimations, they indicate that ozone may significantly reduce crop yields in the future in China.

\section{Conclusions}

Surface level ozone concentrations that would affect crop productivity are fairly recent in China. While there is not enough monitoring or crop loss data available, several conclusions can be drawn. 
Table 4

Crop loss estimated in China in 1990 and 2020

\begin{tabular}{|c|c|c|c|c|c|c|c|c|c|}
\hline \multirow[t]{3}{*}{ Estimator } & \multirow[t]{3}{*}{ Region } & \multicolumn{8}{|c|}{ Crop loss caused by tropospheric ozone (\%) } \\
\hline & & \multicolumn{4}{|l|}{$1990 \mathrm{~s}$} & \multicolumn{4}{|l|}{2020} \\
\hline & & Winter wheat & Rice & Corn & Soybean & Winter wheat & Rice & Corn & Soybean \\
\hline Wang and Mauzerall, 2004 & China & $6-13$ & $3-5$ & $1-9$ & $15-23$ & $7-63$ & $7-10$ & $16-64$ & 24-64 \\
\hline Aunan et al., 2000 & China & $0-1.7$ & $1.1-1.5$ & $0-2.8$ & $1.9-11.7$ & $2.3-13.4$ & $3.7-4.5$ & 7.2 & $17.8-20.9$ \\
\hline Feng et al., 2003 & Yangtze River Delta & $>10$ & $<5$ & & & & & & \\
\hline Wang et al., 2005 & Yangtze River Delta & $20-30$ & & & & & & & \\
\hline
\end{tabular}

1. There appears to be widespread occurrence of levels of surface ozone that exceed background levels that could cause crop losses.

2. While some experiments have been conducted on ozone effects on crop loss and some modeling of ozone effects on crop losses has been done, much remains to be learned about ozone effects on crop losses. Long-term experiments with different crops and local conditions need to be done, with both open-top chambers and the protectant EDU, to develop a database for crop losses. Models that relate well to crops and conditions in China need to be developed.

3. A national program of air quality monitoring for ozone, integrated with assessment of ozone effects on crop losses, needs to be developed and implemented.

\section{Acknowledgments}

This research was supported by Ministry of Science and Technology of China under 973 project (No. 2002CB410803).

\section{References}

An, L., Wang, X., 1994. Effects of ozone on growth of spring wheat and the prevention of rare earth to ozone injury. Acta Ecologica Sinica 14, 76-98 (in Chinese).

Ashmore, M.R., 2005. Assessing the future global impact of ozone on vegetation. Plant, Cell and Environment 28, 949-964.

Aunan, K., Berntsen, T., Seip, H., 2000. Surface ozone in China and its possible impact on agricultural crop yields. Ambio 29, 294-301.

Bai, Y., Wang, C., Liu, L., Guo, J., Wen, M., 2002. A diagnostic experiment and study of the influence of $\mathrm{O}_{3}$ on Pakchoi. Journal of Applied Meteorological Science 13, 364-370 (in Chinese).

Bai, J., Xu, Y., Chen, H., Wang, G., Shi, L., Men, Z., Huang, Z., Kong, G., 2003. The variation characteristics and analysis of ozone and its precursors in the Dinghushan Mountain forest area. Climatic and Environmental Research 8 (3), 370-380 (in Chinese).

Chameides, W.L., Kasibhatla, P.S., Yienger, J., Levy II, H., 1994. Growth of continental-scale metro-agro-plexes, regional ozone pollution, and world food production. Science 264, 74-77.

Chameides, W.L., Li, X., Tang, X., Zhou, X., Luo, C., Kiang, C., St John, J.C., Saylor, R.D., Liu, S., Lam, K.S., Wang, T., Giorgi, F., 1999. Is ozone pollution affecting crop yields in China? Geophysical Research Letters 26, 867-870.

Chen, J., Lan, Z., Su, Z., Zen, J., Wang, Y., 1996. The dynamic stress exposure test on tobacco blade disease caused by $\mathrm{SO}_{2}$ and $\mathrm{O}_{3}$. Chinese Journal of Applied Environmental Biology 2, 189-192.

Coyle, M., Smith, R.I., Fowler, D., 2003. An ozone budget for the UK: using measurements from the national ozone monitoring network; measured and modelled meteorological data, and a 'big-leaf' resistance analogy model of dry deposition. Environmental Pollution 123, 115-123.

Elagoz, V., Manning, W.J., 2005. Factors affecting the effects of EDU on growth and yield of field-grown bush beans (Phaseolus vulgaris L.) with varying degrees of sensitivity to ozone. Environmental Pollution 136, 385-395.

EPA, 1996. Air quality criteria for ozone and related photochemical oxidants. United States Environmental Protection Agency (EPA). pp.1-1 to 1-33.

Feng, Z., Jin, M., Zhang, F., 2003. Effects of ground-level ozone $\left(\mathrm{O}_{3}\right)$ pollution on the yields of rice and winter wheat in the Yangtze River Delta. Journal of Environmental Science (China) 15, 360-362.

Gao, J., Wang, T., Ding, A., Liu, C., 2005. Observational study of ozone and carbon monoxide at the summit of mount Tai (1534 m a.s.l) in central-eastern China. Atmospheric Environment 39, 4779-4791.

Gatta, L., Mancino, L., Federico, R., 1997. Translocation and persistence of EDU (ethylenediurea) in plants: the relationship with its role in ozone damage. Environmental Pollution 96, 445-448.

Grennfelt, P., Munthe, J., 2005. Current and future issues in transboundary air pollution science and policy. Ambio 34, 1 .

He, D., Huang, M., 1993. Numerical simulation of tropospheric ozone over China. Scientia Atmopsherica Sinica 17, 741-749 (in Chinese).

He, K., Hong, H., Zhang, Q., 2002. Urban air pollution in China: Current status, characteristics, and progress. Annual Review of Energy and the Environment 27, 397-431.

Hogsett, W.E., Tingey, D.T., Lee, E.H., 1988. Ozone exposure indices: concepts for development and evaluation of their use. In: Heck, W. (Ed.), Assessment of Crop Loss From Air Pollutants. Elsevier Science Publishers, London, pp. 107-138.

Hong, S., 1988. The time-space distribution pattern for atmospheric ozone over the mount Omei. Research of Environmental Sciences 1, 31-37 (in Chinese).

Huang, Y., Wang, X., 1991. The effects of ozone on photosynthesis of pepper in different growing stages. Agro-Environmental Protection 10 (2), 60-63 (in Chinese).

Huang, H., Wang, C., Bai, Y., Wen, M., 2004. A diagnostic experimental study of the composite influence of increasing $\mathrm{O}_{3}$ and $\mathrm{CO}_{2}$ concentration on soybean. Chinese Journal of Atmospheric Sciences 28, 601-612 (in Chinese).

Jiang, B., Totsuka, T., 1995. Effect of $\mathrm{O}_{3}$ exposure on plant photosynthesis. Journal of Shanxi Agricultural University 15, 139-141 (in Chinese).

Jin, M., Feng, Z., 2000. Effects of ozone on membrane protective system of winter wheat leaves. Acta Ecologica Sinica 20, 444-447 (in Chinese).

Jin, M., Feng, Z., Zhang, F., 2000. Effects of ozone on membrane lipid peroxidation and antioxidant system of rice leaves. Journal of Environmental Science 21, 1-5 (in Chinese).

Jin, M., Feng, Z., Zhang, F., 2001. Impacts of ozone on the biomass and yield of rice in open-top chamber. Journal of Environmental Science (China) 13, 233-236.

Li, X., He, Z., Fang, X., Zhou, X., 1999. Distribution of surface ozone concentration in clean areas of China and its possible impact on crop yields. Advances in Atmospheric Sciences 16, 154-158 (in Chinese).

Li, X., An, J., Wang, Y., Chen, W., Hu, F., Chen, H., Shi, L., 2003a. Atmospheric ozone observed in summer on meteorological tower in Beijing. China Environmental Science 23, 353-357 (in Chinese).

Li, S., Jin, D., Chen, T., Pu, Y., Jin, Q., Jin, F., 2003b. Measurements and analyses of the concentrations of $\mathrm{O} 3, \mathrm{NOx}, \mathrm{CO}$ and $\mathrm{SO} 2$ over Yanji in 
Spring. Journal of Yanbian University (Natural Science) 29 (4), 257-260 (in Chinese).

Luo, C., St John, J.C., Zhou, X., Lam, K.S., Wang, T., Chameides, L., 2000. A nonurban ozone air pollution episode over eastern China: Observations and model simulations. Journal of Geophysical Research 105, 1889-1908.

Manning, W.J., 2000. Use of protective chemicals to assess the effects of ambient ozone on plants. In: Agrawal, S.B., Agrawal, M. (Eds.), Environmental Pollution and Plant Response. Lewis Publishers, Boca Raton, FL, pp. 247-258.

Manning, W.J., 2005. Establishing a cause and effect relationship for ambient ozone exposure and tree growth in the forest: Progress and an experimental approach. Environmental Pollution 137, 443-453.

Nie, H., Nie, S., Wang, Z., Tang, J., Zhao, Y., 2004. Characteristic analysis of surface ozone over clean area in Qinghai-Tibet Plateau. Arid Meteorology 22 (1), 1-7 (in Chinese).

Qiu, Q., Jing, L., An, L., Yang, C., 1994. Influences of $\mathrm{O}_{3}$ on the metabolism of nucleic acid and soluble protein in the leaf of wheat seeding. Journal of Gansu Sciences 6, 36-39 (in Chinese).

Su, W., Song, Z., Luo, C., Zhang, Q., Yuan, J., Wilson, W.E., 1987. Ozone pollution in Beijing-Tianjin region. Acata Scientiae Circumstantiae 7, 503-507 (in Chinese).

Sun, H., Li, Q., Zhu, G., Zhou, X., 1998. An exploration on the aetiological agent of tobacco weather fleck. Acta Phytophylacica Sinica 25, 305-310 (in Chinese).

Tiwari, S., Agrawal, M., Manning, W.J., 2005. Assessing the impact of ambient ozone on growth and productivity of two cultivars of wheat in India using three rates of application of ethylenediurea (EDU). Environmental Pollution 138, 153-160.

Wang, X., Guo, Q., 1990. The effects of ozone on respiration of the plants Fuchsia hybrida Voss. And Vicia faba L. Environmental Science 11, 31-33 (in Chinese).

Wang, X., Huang, Y., 1999. Effects of magnetized water on the growth and yield of red pepper (Capsicum annuum) and on prevention of $\mathrm{O}_{3}$ injury. J. Lanzhou University (Natural Sciences) 25, 130-133 (in Chinese).

Wang, X., Mauzerall, L., 2004. Characterizing distributions of surface ozone and its impact on grain production in China, Japan, and South Korea: 1990 and 2020. Atmospheric Environment International-Asia 38, 4383-4402.

Wang, X., Men, X., 1991. Effects of ozone on pollen germination and growth of pollen tubes of horticultural plants. Xibei Zhiwu Xuebao 11, 50-56 (in Chinese).

Wang, X., He, J., Huang, Y., 1991. Effect of ozone on photosynthetic intensities of broad bean (Vicia Faba L.) and the prevention of Mefluidide for ozone impact. Acta Ecologica Sinica 11, 189-190 (in Chinese).

Wang, X., Chen, X., Lu, X., 1993. A study on prevention of calcium to the wheat injury by ozone. Acta Botanica Boreal Occident Sinica 13, 163-169 (in Chinese).
Wang, X., Han, Z., Lei, X., 2003. Study on ozone concentration change of Quangzhou District. Acta Scientiarum Naturlium Unversitatis Sunyatsen 42, 106-109 (in Chinese).

Wang, H., Kiang, C.S., Tang, X., Zhou, X., Chameides, W.L., 2005. Surface ozone: A likely threat to crops in Yangtze delta of China. Atmospheric Environment 39, 3843-3850.

Wu, J., Jiang, W., Chen, X., Wang, W., Guo, S., Xie, Y., Liu, H., 2004. Simulation of effects to tropospheric ozone over southeast Asia and south China from biomass burning. Environmental Science 25, 1-6.

Xinhua News Agency, 2004, Total grain production amounts to 0.43 billion tones, $<$ http://news.xinhuanet.com/newscenter/2004-02/09/content_1304918.htm >. (in Chinese).

Yang, J., Lu, D., 2004. Simulation of stratosphere-troposphere exchange effecting on the distribution of ozone over eastern Asia. Chinese Journal of Atmospheric Sciences 28, 579-588 (in Chinese).

Yang, T., Yin, Q., Ding, Y., Zhang, Y., 2004. Relationships between ozone injury and stoma parameters and activities of antioxidant enzymes. Acta Phytoecologica Sinica 28, 672-679 (in Chinese).

Yao, K., Chen, Y., Zhang, H., Huang, M., Shen, Z., Shi, L., 1995. Measurements and analysis of $\mathrm{SO}_{2}$ and $\mathrm{O}_{3}$ near the ground surface in "the first eco-agriculture village"-Xiaozhangzhuang and Hefei areas. Plateau Meteorology 14, 334-341 (in Chinese).

Yin, Y., Li, C., Ma, G., Cui, Z., 2004. Ozone concentration distribution of urban. Environmental Science 25, 16-20 (in Chinese).

Yu, F., Xu, Y., Qin, W., 1994. The effect of SO2, NO2, O3 and their combination on ethylene emission. Journal of Environmental Science 5, 69-71 (in Chinese).

Zhang, Y., Zheng, Y., Lou, W., 2003. State of ozone pollution and its change in the center urban area of Shanghai. Environmental Monitoring Management and Technology 15, 15-20 (in Chinese).

Zhang, M., Xu, Y., Uno, I., Akimoto, H., 2004. A numerical study of tropospheric ozone in the springtime in east Asia. Advance in Atmospheric Sciences 21, 163-170.

Zhao, C., Peng, L., Sun, A., Qin, Y., Liu, H., Li, W., Zhou, X., 2004. Numerical modeling of tropospheric ozone over Yangtze Delta region. Acta Scientiae Circumstantiae 24, 525-533 (in Chinese).

Zheng, X., Zhou, X., Qin, Y., Tang, J., Li, W., 2003. Analysis for a case of ozone downward transport from stratosphere to troposphere as observed over Xining, China. Acta Meteorologica Sinica 61, 257-266 (in Chinese).

Zheng, Y., Stevenson, K.J., Barrowcliffe, R., Chen, S., Wang, H., Barnes, J.D., 1998. Ozone levels in Chongqing: a potential threat to crop plants commonly grown in the region? Environmental Pollution 99, 299-308.

Zhou, X., 2004. The Interaction Between the Atmosphere and Ecosystems in Yangtze Delta Region. Meteorological Press, Beijing (in Chinese).

Zhou, K., Feng, Y., 2001. Influence of ozone on the growth of cultivating vegetables in Guangzhou. Journal of Huangzhong Agricultural University 20 (4), 344-347 (in Chinese). 